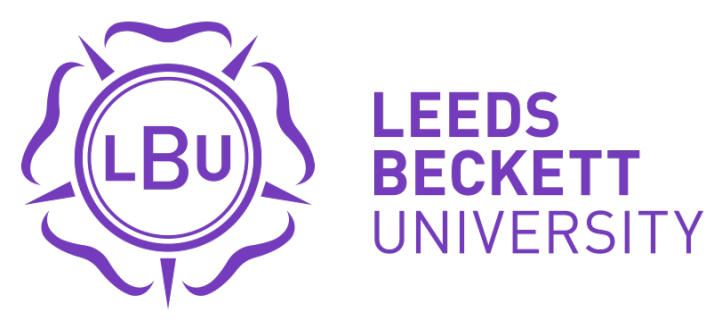

Citation:

Lodorfos, G and Kostopoulos, G and Kaminakis, K (2015) The impact of service delivery system effectiveness on service quality: A hierarchical approach. International Journal of Business Performance Management, 16 (2-3). 169 - 181. ISSN 1368-4892 DOI: https://doi.org/10.1504/IJBPM.2015.068721

Link to Leeds Beckett Repository record:

https://eprints.leedsbeckett.ac.uk/id/eprint/1574/

Document Version:

Article (Accepted Version)

The aim of the Leeds Beckett Repository is to provide open access to our research, as required by funder policies and permitted by publishers and copyright law.

The Leeds Beckett repository holds a wide range of publications, each of which has been checked for copyright and the relevant embargo period has been applied by the Research Services team.

We operate on a standard take-down policy. If you are the author or publisher of an output and you would like it removed from the repository, please contact us and we will investigate on a case-by-case basis.

Each thesis in the repository has been cleared where necessary by the author for third party copyright. If you would like a thesis to be removed from the repository or believe there is an issue with copyright, please contact us on openaccess@leedsbeckett.ac.uk and we will investigate on a case-by-case basis. 
The Impact of Service Delivery System Effectiveness on Service Quality:

\section{A Hierarchical Approach}

Giannis Kostopoulos, $\mathrm{PhD}$

Senior Lecturer

School of Strategy, Marketing and Communication

Leeds Metropolitan University

Email: i.kostopoulos@leedsmet.ac.uk

George Lodorfos, $\mathrm{PhD}$

Head of School

School of Strategy, Marketing and Communication

Leeds Metropolitan University

Email: g.lodorfos@leedsmet.ac.uk

Kostas Kaminakis, $\mathrm{PhD}$

Athens University of Economics and Business

Email: kkaminakis@aueb.gr 
The Impact of Service Delivery System Effectiveness on Service Quality:

\title{
A Hierarchical Approach
}

\begin{abstract}
This article focuses on the effectiveness of the Service Delivery System (SDS) and reexamines its influence on customers' perceived service quality. In this study, the influence of four specific indicators of the SDS' effectiveness (namely front line employees' role performance, their adaptability to individual customer needs, the effectiveness of their coordination and the effectiveness of the service process' control) on perceived service quality is tested. In doing so, a hierarchical approach has been taken integrating both managers' and customers' views. The results confirm the positive influence of three variables on perceived service quality (role performance, effectiveness of coordination and effectiveness of process' control). On the contrary, the influence of employees' adaptability was not found significant.
\end{abstract}

Keywords: Service delivery system, service quality, employee adaptability 


\section{Introduction}

Delivering services of high quality is an important pursuit for service providers that seek to create and provide value to their customers (Grönroos and Ravald, 2011). Through the provision of high levels of service quality, companies can achieve increased customer satisfaction, loyalty and therefore long-term profitability (Zeithaml and Bitner, 2000). In order to provide high levels of service quality and therefore create value for their customers, service organisations need to plan the delivery of their services and to ensure the successful implementation of the actual plan (Parasuraman, Berry and Zeithaml 1985, 1988). Therefore, good planning and effective implementation of the developed delivery plans are key factors for the Service Delivery System (SDS). Furthermore, continuous improvement of service procedures contributes to the optimisation of SDS and enhances the organisation's standards of service.

In the pertinent literature, a great numbers of normative studies demonstrate that the effectiveness of the SDS influences positively and significantly customers' perceptions of the quality of the service that they receive (e.g. Hensel, 1990; Kingman-Brundage, 1991). Similarly, many studies have proved, through empirical research, the positive influence of several variables of the SDS on perceived service quality (e.g. Parasuraman, Berry and Zeithaml 1988; Hartline and Ferrel, 1996).

However, to our knowledge, very few studies group specific variables and examine the overall influence of the SDS Effectiveness on service quality, through the direct influence of the individual SDS variables on it. Most studies (Hartline and Ferrell, 1996; Bettencourt and Brown, 1997), both the normative and the empirical ones, either have not focused on particular variables of SDS effectiveness, considering the SDS as a unified variable and therefore have not explored individual influences on service quality, or have examined the 
influence of specific variables, but have ignored the role of these variables as indicators of the SDS effectiveness.

To fill this gap in the literature, the present study follows a hierarchical approach that integrates both the customers' and the company's view. On this basis, it attempts to examine the relationship between four specific indicators of the SDS effectiveness (namely front line employees' role performance, their adaptability to individual customer needs, the effectiveness of the coordination and the effectiveness of the process' control) on customers' perceptions on the quality of the provided service.

The following paragraphs present at first the underlying theory regarding our study's core variables. Next, we develop the research hypotheses of the study's conceptual framework. In the following chapters, the methodology and the results of our empirical investigation are described. Finally, the implications of our findings are presented alongside with the study's limitations and suggestions for further research.

\section{Literature Review}

In general, system effectiveness is described as the capability of producing a specific, desired effect, or in other words "getting the right things done" (Druker, 2004). In a services management context, service delivery system is defined as "the structure (facilities, equipment, etc.), infrastructure (job design, skills, etc.) and processes for delivering a service" (Goldstein et al. 2002, p. 132). From these definitions it becomes apparent that SDS effectiveness is related to the degree to which a system's objectives have been achieved and therefore, an effective SDS is the one that is capable of delivering the outcomes for which it was originally designed and developed (Kingman-Brundage, 1991). Service delivery systems normally should be able to produce several positive outcomes, ranging from reduced costs, 
increased availability of efficient operations, improved service quality and optimum customer experience (Walley and Amin, 1994).

Notably, many scholars have argued that the main aim of a service delivery system is to bridge the gap between customer expectations and customer experience (e.g. Lovelock, 1984; Armistead, 1990). The SDS is in fact the medium through which service employees attempt to meet the quality standards set by the management, in order to close the third gap of services quality, which refers to the gap between service quality specifications and the actual service delivery (Parasuraman et al, 1985). Therefore, an effective SDS must lead to high levels of service quality both in terms of actual technical quality and it terms of customers' perceptions, since customers are far more likely to evaluate a service positively when the company effectively provides the value promised to them (Zeithaml et al, 1988; Parasuraman et al, 1991).

In order to assess the effectiveness of the SDS most researchers either measure specific outputs of the system, such as the times required for task execution, costs, etc. (e.g. Haynes and DuVall, 1992; Mandell, 1991) or use proxy variables and assess the effectiveness of its most important determinants (e.g. Ponsignon, Smart and Maull, 2011). In this study, we are following the second approach, identifying the key factors that determine SDS effectiveness and exploring their influence on service quality. Specifically, we argue that the most important determinants of a service system's effectiveness are the front line employees' role performance, their ability to adapt to individual customer needs, the effectiveness of their coordination and the effectiveness of the process' control (Galbraith, 1973; Bettencourt and Brown, 1997). Hence, our conceptual framework describes the direct positive influence of the aforementioned variables on perceived service quality (Figure 1).

\section{Insert Figure 1}


Employees' role performance and adaptability are considered as major determinants of SDS effectiveness, because they reflect the most important outcome of the SDS, which is its ability to satisfy customer needs and create customer value. As an SDS constitutes of multiple, interdependent service processes, which are organised hierarchically and are integrated within a specific process architecture (Sousa and Voss 2006), the coordination and the control of these service processes should also be taken into account in the conceptualization of SDS effectiveness. This is because these two factors will determine the way this integrated set of processes will be embedded into the service delivery and therefore the system's effectiveness.

\subsection{Employee Role Performance}

Service employees, both the ones working in the front line and those who support them in the back office, are an inseparable part of the service and their performance is crucial for the success of the service delivery (Lovelock, 1985). In order to perform well, front line employees must enact their role in the service delivery both efficiently and effectively (Bitner et al, 1997). Their role in the SDS is either provided by their supervisors or described in a formal job description, blueprint etc. and it reflects customer needs, standards set by management and service level agreements. Hence, by effectively performing their predefined role, service employees can contribute to the achievement of the company's quality standards and bridge the gap between service delivery and customer expectations (Zeithaml et al, 1988).

Based on the above arguments is reasonable to suggest that there is strong relationship between employees' role performance and several positive organizational outcomes, such as increased service quality (Bowen and Jones, 1986; Hartline and Ferrell, 1996; MacKenzie, Podsakoff and Ahearne, 1998). Therefore, we formulate the following research hypothesis: 
H1: Front line employees' role performance influences positively customers' perceptions on the quality of service.

\subsection{Employee Adaptability}

Employees' ability to adapt must not be confused with random deviations in their behaviour and performance. This is because only deviations that aim to satisfy specific customer needs, contribute to the service delivery (Weitz et al, 1986). Therefore, adopting previous definitions, in this study we define employee adaptability as "the ability of employees to adjust their behaviour to meet the needs of each customer encounter" (Hartline and Ferrell, 1996). Based on this definition, employees' adaptability is a crucial factor in the company's effort to meet the pre-defined quality standards, so is considered as an important indicator of SDS effectiveness.

As noted by previous researchers, front line employees' ability to adapt to individual customers' behaviour is directly related to service quality (Hartline and Ferrell, 1996; Chebat and Kollias, 2000). More adaptable employees, especially if they are empowered, will find it easier to offer individual attention to customers and hence satisfy their individual needs (Singh, 2000). On the contrary, employees who do not have the necessary ability or willingness to adapt their behaviour to the circumstances (e.g. the customer's needs) and just follow their supervisors' instructions cannot deliver high quality of service (Humphrey and Ashforth, 1994; Sony and Mekoth, 2012). In fact, satisfied customers most of the times recognise employees' ability to understand their individual needs and offer them a customised service as the main source of their satisfaction (Bitner and Hubbert, 1994). Therefore, we formulate the following research hypothesis:

H2: Front line employees' ability to adapt to individual customers' behaviour influences positively customers' perceptions on the quality of service. 


\subsection{Effectiveness of Employee Coordination}

Employee coordination describes the degree to which employees work successfully together to achieve mutually agreed goals (Ellinger et al, 2011). The effective coordination (or cooperation) of employees has always a beneficial influence on a company's organizational function (Van de Ven, Delbecq and Koenig, 1976; Galbraith and Lawler, 1993; Gittel and Weiss, 2004). Service providers in particular, always aim to improve the communication between employees and to optimise the way they work together in teams and departments. This is because better coordination among individual employees, apart from improving the company's overall organizational function, also enables organizations to generate value for their customers (Zeithaml et al, 1988; Demirbag et al, 2012).

For this to happen, both the coordination of tasks carried out from employees that work in the same department or team and the intra-departmental coordination of activities must be improved (Saraph et al, 1989). Through successful coordination of activities a service organization avoids double efforts, bottlenecks and miscommunication during the service delivery (Lings and Brooks, 1998). By avoiding these operational, organisational and managerial failures, the effectiveness of the SDS is ensured and its efficiency is improved, resulting hence in better customer evaluations. Regarding the latter, of great importance is the optimisation of the coordination between the front line and the back office personnel since this is a necessary factor for the success of the service delivery (Zeithaml and Bitner, 2000; Zomerdijk and Vries, 2007). Based on the above discussion the third hypothesis is:

H3: The effectiveness of the employees' coordination influences positively customers' perceptions on the quality of service. 


\subsection{Effectiveness of Process Control}

One more variable of the SDS that influences positively the quality of the service is the effectiveness of the process control (Zeithaml et al, 1988; Parasuraman et al, 1991). Adopting previous theoretical arguments, for the purpose of this study we define process control as the sum of the systems and procedures for controlling the work flow and the utilization of capacity resources in order to meet specific performance standards (Armistead, 1990). Such procedures, which include the use of specific standards, performance measurement tools and control charts, can improve both the effectiveness and the efficiency of the service delivery process (Haynes and DuVall, 1992; Antony et al, 2007).

Through the effective control of the SDS, the service provider continuously monitors, evaluates and refines the service delivery process in order to make it more effective, more cost-efficient and more customer-driven. Therefore, the control process continuously improves the service delivery and upgrades the quality of the service provided to customers (Zeithaml et al, 1988; Seth, Deshmukh and Vrat, 2005). Since it is an inseparable part of the SDS, any improvement in the process control will result into more effective and efficient delivery procedures that result into better customer service (George and Gibson, 1991). On this basis the fourth and final hypothesis of this study is:

H4: The effectiveness of the service process control influences positively customers' perceptions on the quality of service.

\section{Methodology}

In order to empirical test the research hypotheses data was collected from the hotel service sector in Greece. Greece was chosen because it has a service economy that is based heavily on tourism and hospitality. In order to generalise the results to the population, a primary, 
quantitative research was carried out based on structured questionnaires (Parasuraman et al, 2006). Since the conceptual framework includes both customer and organizational variables, data from both managers and customers were collected. For that reason, two different questionnaires were designed, one for hotel managers and one for hotel customers. In order to ensure that the collected sample is representative of the population, data collection was carried out through a two-stage cluster sampling method (Royall, 1976). Following this approach, the first stage involved the random selection of 389 hotels from the total population of hotels in large cities in Greece. From the 389 hotels we contacted, 120 agreed to participate in our study, resulting in a response rate of $31 \%$ at this stage.

In the second stage the "key informant" method was followed (Kumar, Stern, \& Anderson, 1993 ) in order to collect data on the service delivery system. Hence, in each hotel a structured questionnaire was completed by a manager who had a good knowledge of the hotel's service delivery procedures. The list of the participants includes managers responsible for service delivery such as, operations directors, marketing directors or general managers (for the complete list of the key informants see Table 1).

\section{Insert Table 1}

At the same stage, in order to collect customer data, with the hotel managers' approval, 5 customers were personally interviewed on the hotels' premises. After discarding 15 unusable customer questionnaires, the total sample consisted of 120 questionnaires from managers and 585 questionnaires from customers.

In order to measure the variables we used adaptations of reliable likert type scales previously developed and used in other studies. Specifically, the scales developed by Jaworski and MacInnis (1989) were used in order to measure the effectiveness of the coordination and the effectiveness of the process control. The scale developed by Bettencourt and Brown 
(1997) was employed to measure employees' role performance, whereas to capture employee adaptability we used the scale of Hartline and Ferrell (1996). Finally, to measure perceived service quality the 22 items SERVPERF scale developed by Cronin and Taylor (1992) was used, which is based on the SERVQUAL model developed by Parasuraman et al (1985). For each scale, the average of all scale items was calculated and the outputs represent the final variables which were used in the analysis of the data.

In order to assess the scales' unidimensionality, validity and reliability Confirmatory Factor Analysis (CFA) was employed and the corresponding Cronbach a and Composite Reliability coefficients were calculated. As the results of the CFA indicate (Table 2), all scales were indeed proven to be unidimensional and valid in terms of discriminant and convergent validity. All measures were also found internally consistent as reflected by construct reliability, which was assessed through Cronbach a and Composite Reliability (Table 2).

\section{Insert Table 2}

The continuity and normality of all the variables were also tested. Kurtosis and Asymmetry coefficients values for all variables are between -1 and 1 and the p-value of the KolmogorovSmirnov normality test for all variables is greater than 0.05 . These results indicate that the variables used in the analysis can be considered continuous and they are in approximation following a normal distribution (Table 3 presents all variables' Kurtosis and Asymmetry coefficients, the p-value of the Kolmogorov-Smirnov test and their most important descriptive statistics).

Insert Table 3 


\section{Data Analysis}

In order to test the validity of this study's conceptual framework, data collected from both managers and customers of the hotels were combined. In doing so, Hierarchical Linear Modelling was employed (Raudenbush et al, 2004). Service quality was used as level-1 variable, and employees' role performance, their adaptability to individual customer needs, the effectiveness of the coordination, as well as the effectiveness of the process control were used as level-2 variables. All level 1 variables were grand-mean centred, as recommended by Hofmann and Gavin (1998).

Since the customer data were nested within each hotel (Byrne, 2006), the analysis for the null model was initially run, having service quality as a predicted variable and no predictors at either level 1 or level 2 (Bryk \& Raudenbush 1992). As indicated from the results of the analysis of level $1(\mathrm{x} 2=356,62 / \mathrm{p}<0,01)$ the intercept term varies across groups, which means that customer data are indeed nested within each hotel and therefore a hierarchical approach is appropriate. This conclusion is also confirmed from the intraclass correlation coefficient (ICC) of the predicted variable which shows that $39 \%$ of this variable's variance could potentially be explained by the level-2 predictor (Raudenbush et al, 2004).

After the confirmation of the suitability of the hierarchical approach, the validity of the proposed Hierarchical Linear Model presented below was tested:

$\mathrm{SQij}=\gamma 00+\gamma 01 * \mathrm{EOCj}+\gamma 02 * \mathrm{ADAPTj}+\gamma 03 * \mathrm{ERPj}+\gamma 04 * \mathrm{EPCj}+\mathbf{u} 0 \mathrm{j}+\mathbf{r i j}$

Where,

SQ: Service Quality, EOC: Effectiveness of Coordination, ADAPT: Employee Adaptability ERP: Employee Role Performance, EPC: Effectiveness of Process control 
The results of the analysis (Table 4) indicate that service quality is significantly and positively influenced by the variables that capture the Effectiveness of Coordination $(\gamma=$ $0.317 / \mathrm{SE}=0,110 / \mathrm{p}<0,05)$, Employee Role Performance $(\gamma=0.616 / \mathrm{SE}=0,178 / \mathrm{p}<0,001)$, and the Effectiveness of Process Control $(\gamma=0.649 / \mathrm{SE}=0,130 / \mathrm{p}<0,001)$. Hence, hypotheses H1, H3 and H4 are confirmed. On the contrary, the results of the analysis don't support the acceptance of hypothesis H2, since the influence of Employees' Adaptability on Service Quality was not found significant $(\gamma=0.050 / \mathrm{SE}=0,118 / \mathrm{p}>0,05)$.

\section{Insert Table 4}

\section{Conclusions - Discussion}

In order to create customer value, service providers must ensure that the service they offer to their customers is of high quality. The most important contribution of this study is that it identifies the dimensions of the service delivery system's (SDS) effectiveness that actually influence positively customers' perceptions of the quality of the service that they receive. Although there is research evident to suggest that an effective SDS leads to high service quality (e.g. Hartline and Ferrell, 1996; Bettencourt and Brown, 1997), this study is one of the first to confirm a number of factors that contribute to high service quality, namely employees' role performance, the effectiveness of the coordination and the effectiveness of the process control on perceived service quality. These conclusions highlight the need for well-designed service systems that lead to well-coordinated and controlled delivery procedures and enable front line employees in enacting their role in the system efficiently and effectively. In that way a service provider will be able to capitalise on the positive outcomes of a SDS, improve customers' perceptions on the quality of the service they receive and create recognised value.

The results of the present study also indicate that the influence of employees' ability to offer customised solutions to customers on perceived service quality was not found 
significant. This conclusion is contrary to what previous studies have indicated (e.g. Hartline and Ferrell, 1996; Gwinner et al, 2005). One explanation for this finding could be that if the service provider's plan is well thought out and executed then employees' adaptability becomes less significant. In this case, individual employees' ability to adapt their behavior to customer needs is not necessary because of the SDS's high standards of service quality.

On the other hand, if the SDS does not work as effectively as it was supposed to, even if front line employees are able to offer individual attention to customers, their perceptions on the quality of the service will not improve dramatically. In most of these cases, customers will view the divergent behavior of front line employees as ad hoc and this will not be enough to provoke positive evaluation and/or positive perceived service quality. This conclusion does not underestimate the importance of employees' adaptability, which should be fostered and enabled by well-designed SDS systems.

All the aforementioned conclusions offer useful implications for practitioners regarding the management of the SDS with the aim of offering value to customers. The notion of perceived service quality incorporates several dimensions of customer value (Sweeney, Soutar, and Johnson, 1999), such as technical value (e.g. reliability, responsiveness), emotional value (e.g. empathy) and even social value (e,g, tangibles, Zeithaml et al, 1988). The results of this study offer an insight on how the SDS should be managed in order to optimise the value a service provider offers to its customers. The desired outcomes of an effective SDS (employee role performance, effective coordination, effective process control) should drive the SDS design and the management process, in order to enable improvement on both actual and perceived service quality to occur. In that case a service provider can have a robust SDS that maintains high performance even when employees' adaptability to individual customers' needs is relatively low. 


\section{Limitations and Suggestions for Further Research}

Certain limitations of the present study should be considered. The first limitation has to do with the conceptual framework of this investigation and particularly with its relatively limited breadth. Future research should also examine additional employee related dimensions of the service delivery system (SDS) effectiveness such as, employee role stressors (role ambiguity, role conflict), employee job satisfaction etc. as well as, other customer related service outcomes apart from perceived service quality (e.g. perceived value, re-purchase intention). In future research the possible unification of the several indicators of SDS effectiveness in one overall factor should also be examined.

Another limitation of the study is that it does not distinguish between high-contact and low contact services. The level of contact has been proven to be an important factor in the effectiveness of the service encounter (Surprenant and Solomon, 1987; Skaggs and GalliDebicella, 2012). Therefore, the level of contact should be integrated in any future research on this subject. Finally, future studies could integrate data from managers, front-line employees and customers in a three level design. The incorporation of employees' perspectives will help to increase further the validity of the findings. 


\section{References}

Antony, J., Antony, F. J., Kumar, M., \& Cho, B. R. (2007) "Six sigma in service organisations: Benefits, challenges and difficulties, common myths, empirical observations and success factors." International Journal of Quality \& Reliability Management, Vol. 24 No.3, pp. 294-311.

Armistead, C. (1990) "Service operations strategy: framework for matching the service operations task and the service delivery system.” International Journal of Service Industry Management, Vol. 1 No 2, pp. 6-16.

Bettencourt, L. A., and Brown, S. W. (1997) "Contact employees: relationships among workplace fairness, job satisfaction and prosocial behaviours.” Journal of Retailing, Vol. 73 No. 1, pp. 39-61.

Bitner, M. J., and Hubbert, A. R. (1994), Encounter Satisfaction versus Overall Satisfaction versus Quality: The Customers Voice. in Service Quality: New Directions in Theory and Practice, pp. 79-94.

Bitner, M. J., Faranda, W. T., Hubbert, A. R., \& Zeithaml, V. A. (1997) "Customer contributions and roles in service delivery." International Journal of Service Industry Management, Vol. 8 No. 3, pp. 193-205.

Bowen, D.E. and Jones, G.R. (1986) "Transaction cost analysis of service organizationcustomer exchange", Academy of Management Review, Vol. 11 No 2, pp. 428-441.

Bryk, A. S., \& Raudenbush, S. W. (1992) Hierarchical linear model: Applications and data analysis methods. Newbury Park, CA: Sage.

Byrne, B. M. (2006) Structural Equation Modeling with EQS, 2nd Edition, Multivariate Applications Series. 
Chebat, J. C., \& Kollias, P. (2000) "The impact of empowerment on customer contact employees' roles in service organizations." Journal of Service Research, Vol. 3 No. 1, pp. 66-81.

Cronin J. J., and Taylor, S. A. (1992) "Measuring Service Quality: a Reexamination and Extension.” Journal of Marketing, Vol. 56 No. 2, pp. 55-68.

Demirbag, M., Sahadev, S., Kaynak, E., \& Akgul, A. (2012) "Modeling quality commitment in service organizations: an empirical study." European Journal of Marketing, Vol. 46 No. 6, pp. 790-810.

Drucker, P. (2004) The Daily Drucker: 366 Days of Insight and Motivation for Getting the Right Things Done, Harper Business, 1st edition, N. York.

Ellinger, A. E., Baş, A. B. E., Ellinger, A. D., Wang, Y. L., \& Bachrach, D. G. (2011) "Measurement of organizational investments in social capital: The service employee perspective.” Journal of Business Research, Vol. 64 No. 6, pp. 572-578.

Galbraith, J. (1973) Designing Complex Organizations. Reading, MA: Addison-Wesley.

Galbraith, J., and Lawler, E. (1993) Organizing for the Future: The New Logic of Managing Complex Organizations. San Francisco, CA: Jossey-Bass.

George, W. R., and Gibson, B. E. (1991) Blueprinting - a tool for managing quality in service. in Service Quality - Multidisciplinary and Multinational Perspective, Lexington Books, Lexington, MA.

Gittel, J. H., and Weiss, L. (2004) “Coordination Networks Within and Across Organizations: A Multi-level Framework.” Journal of Management Studies, Vol. 41 No. 1, pp. $127-$ 153. 
Goldstein, S. M., Johnston, R., Duffy J. and Rao J. (2002) "The service concept: the missing link in service design research?," Journal of Operations Management, Vol. 20 No. 2, pp. 121-134.

Grönroos, C., \& Ravald, A. (2011) “Service as business logic: implications for value creation and marketing.” Journal of Service Management, Vol. 22 No 1, pp. 5-22.

Gwinner, K. P., Bitner, M. J., Brown, S. W., \& Kumar, A. (2005) “Service customization through employee adaptiveness." Journal of Service Research, Vol. 8 No. 2, pp. 131148.

Hartline, M. D., and Jones, K. C. (1996) "Employee performance cues in a hotel service environment: influence on perceived service quality, value, and word-of-mouth intentions.” Journal of Business Research, Vol. 35 No. 3, pp. 205-217.

Haynes, R. M., \& DuVall, P. K. (1992) “Service quality management: a process-control approach.” International Journal of Service Industry Management, Vol. 3 No. 1, pp. 1424.

Hensel, J. S. (1990) "Service quality improvement and control: A customer-based approach.” Journal of Business Research, Vol. 20 No. 1, pp. 43-54.

Hofmann, D. A., \& Gavin, M. B. (1998) “Centering decisions in hierarchical linear models: Implications for research in organizations.” Journal of Management, Vol. 24 No. 5, pp. 623641.

Humphrey, R. H., and Ashforth, B. E. (1994) "Cognitive scripts and prototypes in service encounters." Advances in Services Marketing and Management: Research and Practices, Vol. 3 No. 1, pp. 2-15.

Jaworski B. J., and MacInnis D. J. (1989) "Marketing Jobs and Management Controls: Toward a Framework.” Journal of Marketing Research, Vol. 26 No. 4, pp. 406-419. 
Kingman-Brundage, J. (1991) Service Mapping: Gaining a Concrete Perspective on Service System Design. QUIS 3 Conference, Sweden, pp. 14-17.

Kumar, N., Stern, L. and Anderson, J. (1993) "Conducting interorganizational research using key informants", Academy of Management Journal, Vol. 36 No 6, pp. 1633 - 1651.

Lings, I. N., and Brooks, R. F. (1998) "Implementing and Measuring the Effectiveness of Internal Marketing." Journal of Marketing Management, Vol. 14 No 4, pp. 325-351.

Lovelock, C. H. (1985) "Developing and managing the customer-service function in the service sector. The Service Encounter: Managing Employee Customer Interaction in Service Business", 265-280.

MacKenzie, S. B., Podsakoff, P. M., \& Ahearne, M. (1998) "Some possible antecedents and consequences of in-role and extra-role salesperson performance." Journal of Marketing, Vol. 62 No. 1, pp. 87-97.

Mandell, M. B. (1991) "Modelling effectiveness-equity trade-offs in public service delivery systems.” Management Science, Vol. 37 No. 4, pp. 467-482.

Parasuraman, A., Grewal, D., \& Krishnan, R. (2006). Marketing research. Cengage Learning.

Parasuraman, A., Zeithaml, V. A., and Berry, L. L., (1985) “A conceptual model of services quality and its implications for future research." Journal of Marketing , Vol. 49 No. 3 , pp. 41-50.

Ponsignon, F., Smart, P. A., \& Maull, R. S. (2011) "Service delivery system design: characteristics and contingencies." International Journal of Operations \& Production Management, Vol. 31 No. 3, pp. 324-349.

Raudenbush, S., Bryk, A., Cheong, Y. F., and Congdon, R. (2004) HLM 6 - hierarchical linear and non-linear modeling, SSI Scientific Software International, Linconwood, IL. 
Royall, R. M. (1976) "The linear least-squares prediction approach to two-stage sampling." Journal of the American Statistical Association, Vol. 71 No. 355, pp. 657-664.

Seth, N., Deshmukh, S. G., \& Vrat, P. (2005) "Service quality models: a review." International Journal of Quality \& Reliability Management, Vol. 22 No. 9, pp. 913-949.

Singh, J. (2000) "Performance productivity and quality of frontline employees in service organizations." Journal of Marketing, Vol. 64 No. 2, pp. 15-34.

Skaggs, B. C., \& Galli-Debicella, A. (2012) "The effects of customer contact on organizational structure and performance in service firms.", The Service Industries Journal, Vol. 32 No. 3, pp. 337-352.

Sony, M., \& Mekoth, N. (2012) "A typology for frontline employee adaptability to gain insights in service customisation: a viewpoint." International Journal of Services and Operations Management, Vol. 12 No. 4, pp. 490-508.

Sousa, R. and C. A. Voss (2006) "Service Quality in Multichannel Services Employing Virtual Channels," Journal of Service Research, Vol. 8 No. 4, pp. 356-371.

Surprenant, C. F., \& Solomon, M. R. (1987) "Predictability and personalization in the service encounter." The Journal of Marketing, pp. 86-96.

Sweeney, J. C., Soutar, G. N., \& Johnson, L. W. (1999) "The role of perceived risk in the quality-value relationship: a study in a retail environment." Journal of Retailing, Vol. 75 No. 1, pp. 77-105.

Van de Ven, A., Delbecq, A., \& Koenig, R. (1976) "Determinants of coordination modes within organizations.” American Sociological Review, Vol. 41 No. 1, pp. 322-338. 
Walley, P. and V. Amin (1994) "Automation in a Customer Contact Environment," International Journal of Operations \& Production Management, Vol. 14 No. 5, pp. 86100.

Weitz, B. A., Sujan, H., \& Sujan, M. (1986) "Knowledge, motivation, and adaptive behaviour: a framework for improving selling effectiveness." Journal of Marketing, Vol. 50 No. 4, pp. 174-191.

Zeithaml, V. A., Berry, L. L., and Parasuraman, A., (1988) "Communication and Control Processes in the Delivery of Service Quality". Journal of Marketing, Vol. 52 No.2, pp. $35-48$.

Zeithaml, V.A., and Bitner, M.J. (2000) Services Marketing - Integrating Customer Focus across the Firm 2nd Edition The McGraw Companies, Inc., New York.

Zomerdijk, L. G., \& de Vries, J. (2007) "Structuring front office and back office work in service delivery systems: an empirical study of three design decisions." International Journal of Operations \& Production Management, Vol. 27 No. 1, pp. 108-131. 
Figure 1: Conceptual Framework

Service Delivery System Effectiveness

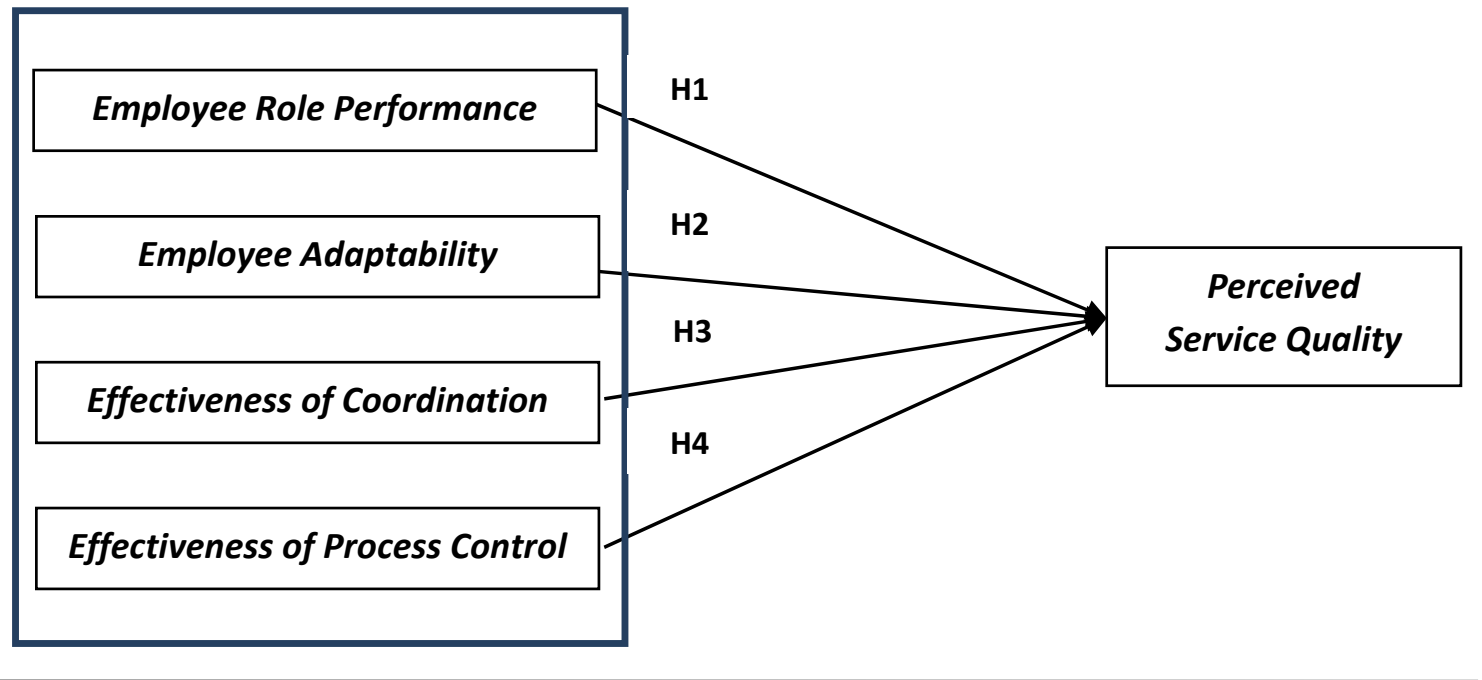


Table 1: Key informants participating in the sample

\begin{tabular}{|lcc|}
\hline Key Informants & Frequency & Percent \\
\hline General Manager - Owner & 36 & $30 \%$ \\
\hline Operations Director & 28 & $23,3 \%$ \\
\hline Department Director & 22 & $18,3 \%$ \\
\hline HR Director & 14 & $11,6 \%$ \\
\hline Quality Control Manager & 7 & $5,8 \%$ \\
\hline Marketing Director & 5 & $4,2 \%$ \\
\hline Other Manager & 8 & $6,7 \%$ \\
\hline Total & $\mathbf{1 2 0}$ & $\mathbf{1 0 0} \%$ \\
\hline
\end{tabular}


Table 2: Confirmatory Factor Analysis

\begin{tabular}{|c|c|c|c|c|c|c|}
\hline Constructs & CFI & TLI & RMSEA & AVE & $\begin{array}{l}\text { Composite } \\
\text { Reliability }\end{array}$ & $\begin{array}{c}\text { Cronbach } \\
\text { a }\end{array}$ \\
\hline Service Quality & 0.936 & 0.915 & 0.081 & 0.59 & 0.81 & 0.932 \\
\hline Employee Role Performance & 0.987 & 0.978 & 0.080 & 0.67 & 0.91 & 0.958 \\
\hline Employee Adaptability & 0.980 & 0.961 & 0.079 & 0.62 & 0.85 & 0.929 \\
\hline Effectiveness of Coordination & 0.949 & 0.924 & 0.076 & 0.71 & 0.75 & 0.843 \\
\hline Effectiveness of Control & 0.963 & 0.922 & 0.092 & 0.58 & 0.76 & 0.942 \\
\hline
\end{tabular}


Table 3: Variables' Descriptive Statistics

\begin{tabular}{|l|c|c|c|c|c|}
\hline \multicolumn{2}{|c|}{ Mean } & St.Dev & Asymmetry & Kurtosis & $\begin{array}{c}\text { Kolmogorov- } \\
\text { Smirnov p-value }\end{array}$ \\
\hline Service Quality & 4.902 & 1.423 & -0.429 & -0.568 & 0.171 \\
Employee Role Performance & 5.045 & 1.168 & $-0,164$ & $-0,465$ & 0,281 \\
Effectiveness of Coordination & 4.982 & 1.084 & $-0,269$ & $-0,499$ & 0,712 \\
Effectiveness of Control & 4.875 & 1.339 & $-0,613$ & $-0,301$ & 0,088 \\
& & & 1.298 & $-0,032$ & $-0,713$ \\
\hline
\end{tabular}


Table 4: Hierarchical Linear Modeling Results

\begin{tabular}{|llllll|}
\hline Fixed Effect & Coefficient & Standard Error & t-ratio & Ap. d.f. & p-value \\
\hline$\gamma_{00}$ & 4.668520 & 0.083931 & 55.623 & 115 & $<0.001$ \\
$\gamma_{01}$ & 0.317007 & 0.110318 & 2.874 & 115 & $<0.05$ \\
$\gamma_{02}$ & 0.050970 & 0.118070 & 0.432 & 115 & 0.667 \\
$\gamma_{03}$ & 0.616106 & 0.178299 & 3.455 & 115 & $<0.001$ \\
$\gamma_{04}$ & 0.649641 & 0.130396 & 3.581 & 115 & $<0.001$ \\
\hline
\end{tabular}

